\title{
A REVIEW OF THE GENUS SCLERURUS OF SWAINSON.
}

\author{
BY \\ Robert RidgWay, \\ Curator of the Department of Birds.
}

The following attempt at a revision of the species of this difficult genus was brought about by the necessity of determining certain unnamed specimens in the National Museum collection. It has proved a difficuit task, rendered particularly so by the confusion of synonyms which had to be unraveled, caused, in part, by the unnecessary "lumping together" of forms which, on comparison of specimens, are found to be perfectly distinct, although it is probable some of them will require a trinomial title when they shall have been found to intergrade with others. For the exact purposes of modern ornithological science it is necessary to recognize such forms by name, their habitat being as well defined as that of perfectly distinct species, and their distinctive characters often, within a given area, as marked.

I have fortunately been able to examine a number of specimens kindly lent for the purpose by the authorities of the American Museum of Natural History, in New York City, to whom my thanks are due, as well as to Dr. P. L. Sclater, of London (now engaged in the preparation of the catalogue of the birds of this family in the British Museum), for the loan of an example of S. albogularis (Swains.), from Venezuela.

\section{Genus Sclerurus SwaInson.}

Sclerurus Swains., Zool. Jour., 1827, 356 (type, S. albogularis Swanss).

Scelurus BURM., Th. Bras., III, 1856, 45.

Tinactor Max., Beitr., III, 1831, 1106 (type, T. fuscus Max.).

Oxypyga Ménétr., Mém. de l'Acad. St. Petersb., vi ser., Sci. Nat., I, 1835, 519 (type, O. scansor MÉnÉtr.,=Myiothera umbretta Licht.).

Generic Char.-Similar to Furnarius, Vieill., but tail-feathers with very stiff, acuminate-pointed shafts, wing more rounded, tarsi shorter and much more compressed. Bill slender, nearly straight to near tip, where rather abruptly decurved; nostrils exposed, oval, with small overhanging membrane; third, fourth, and fifth quills longest, the first shortest; tail decidedly shorter than wing, much rounded or graduated; tarsus about equal to exposed culmen (sometimes a little longer, sometimes a little shorter), much compressed, distinctly scutellate; middle toe (without claw) decidedly shorter than tarsus; lateral claws very unequal in length (outer much the longer); hind toe very stout (about equal to the outer in length), with claw very large. Color: Plain 
brownish, the rump and upper tail-coverts usually more rusty, sometimes bright chestnut; under parts paler than upper, the throat sometimes whitish; no superciliary stripe, and inner webs of primaries unicolored.

QANGE.-Southern Mexico to Argentine Republic.

KEY TO THE SPECIES.

$a^{1}$. Lower rump and upper tail-coverts chestnut, distinctly different from color of back.

$b^{1}$. Chin and throat whitish or grayish, distinctly ifferent from color of chest.

$c^{1}$. Chin and throat uniform dull white or grayish white, the feathers margined or tipped with dark grayish or dusky. Hab., Brazil, south of the Amazon Valley ....................... umbretta (Licht.) (p. 22).

$c^{2}$. Chin and upper throat white, lower throat gray, the feathers without distinct (if any) darker tips or margins.

$d^{1}$. Chest olive-tawny or raw-umber, the belly, etc., grayish olive; upper parts olive, the lower rump and upper twil-coverts bright chestnut. Hab., Venezuela and Tobago ............ S. albogularis (SwaIns.) (p.24).

$d^{2}$. Chest chestnut-brown or burnt-umber, the belly, etc., dull slate-color tinged with dark rusty ; upper parts dark umber-brown, the lower rump and upper tail-coverts dark chestnut. Hab., Costa Rica.

S. canigularis RIDGW. (p. 24).

$b^{2}$. Chin and throat bright russet or rufous-tawny, like color of chest. Hab., Southern Mexico to Peru and Lower Amazons.... S. mexicanus ScL. (p. 25).

$a^{2}$. Lower rump and upper tail-coverts similar in color to back, or only slightly more rufescent.

$b^{1}$. Chin and throat tawny or russet, like chest. Hab., Guiana:

S. caudacutus (VIEILL.) (p. 27).

$b^{2}$. Chin and upper throat with basal portion of feathers whitish or very pale brownish, their tips or terminal margins dark brown or dusky.

$c^{1}$. General color umber or sepia brown.

$d^{1}$. Throat brown, with basal portion of feathers dull brownish-white or pale brownish. Hab., Upper Amazons...........S. fuscus (MAX.) (p. 28).

$d^{2}$. Chin and upper throat white, the feathers tipped or margined with brown or dusky.

$e^{1}$. Chest without spots or distinct streaks of tawny, and general coloration lighter brown.

$f^{1}$. General color deep chocolate-brown ; smaller (wing, 3.30-3.46 ; tail, 2.10 2.30). Hab., Colombia.................... brunneus ScL. (p. 29).

$t^{2}$. General color vandyke-brown, more olivaceous on under parts, the sides of head and neck and upper chest brownish-tawny; larger (wing, 3.95; tail, 3.10). Hab., Eastern Brazil (Bahia).

S. lawrencei RIDGW. (p. 29).

$e^{2}$. Chest with distinct spots or streaks of tawny, and general color much darker brown. Hab., Southern Mexico to Panama.

S. guatemalensis Hartl. (p. 30.)

$c^{2}$. General color olivaceous. Hab., Western Peru.......S. olivascens CaB. (p. 31).

Sclerurus umbretta (Licht.).

Myiothera umbretta Licht., Verz. Doubl., 1823, 43, No. 471 (Bahia).

Myioturdus umbretta Ménétr., Mém. de l'Aead. St. Petersb., vi ser., Sci. Nat., I, 1835, 468 (Bahia).

Formicarius umbrettus GRAY, Gen. B., I, 1840, 211.

Sclerurus umbretta Scl. \& SALv., Nom. Neotr., 1873, 6๕.-SCl. \& Huds., Arg. Orn., I, 1888, 174 (Misiones, Arg. Rep.). 
My'othera cauclacuta LAFr., Mag. de Zool., 1833, pl. 10 (Brazil ; nec Thamophilus caudacutus VIEILL.)

Sclerurus caudacutus Burm., Verz. Mus. Hal. ——, 45; Th. Bras., III, 1856, 45 (New Freiburg; "Scelurus").-CAB., Mus. Hein., II, 1859, 25 (Brazil ; excl. syn. albogularis Sw.).-Scl., Cat. Am. B., 1861, 149 (Brazil ; excl. syn. pt.).-PeLz., Orn. Bras., II Arb., 1869, 86 (Registro do Sai, Rio August, Ypanema, and Borba).-White, P. Z. S., 1882, 610 (Misiones, Arg. Rep.).-Taczan., Orn. du Pérou, II, 1884, 114 (Peru, ex Tschudi).

Oxypyga scansor Ménétr., Mém. Ac. St. Petersb., vi ser., Sci. Nat., I, 1835, 520, pl. 11, (Rio de Janeiro and Minas Geraes).

Tinactor fuscus Max., Beitr., III, 1831, 1106 (part; female only!).

Sp. CHAR.-Above clear brown, becoming bright chestnut on rump and upper tail-coverts; beneath paler, more olive, brown, becoming bright russet on chest (where usually paler shaft-streaks), the throat whitish, with dull brownish margins to feathers; tail dusky.

HAB.-Brazil, south of the Amazon; west to eastern Peru.

Adult male (No. 32796, Brazil; Ed. Verreaux)._A Above clear mummy. brown, duller (more bistre) on pileum, the rump and upper tail-coverts bright chestnut; wing coverts margined with rusty brown; tail chocolate-brown basally, deepening towards tip into brownish black. Sides of head similar to pileum, but slightly paler; chin and upper throat dull brownish-white, the feathers indistinctly margined with brownish; lower throat light tawny-brown, the feathers with paler shaft-streaks; chest bright russet, with similar lighter shaft-streaks; other under parts olivebrown or raw-umber, tinged with brighter brown on sides and flanks and changing to more ruddy brown, or light burnt-umber, on lower tailcoverts. Bill dusky brown, the basal balf of under mandible paler; feet dusky brown. Length (skin), 7.70; wing, 3.85; tail, 3.30 ; exposed culmen, .90 ; tarsus, .90 ; middle toe, .75 .

Adult female (No. 32795, Brazil; Verreaux).-Similar to the male described above, but smaller. Length (skin), 6.70 ; wing, 3.50 ; tail, 2.80; exposed culmen, .90 ; tarsus; .90 ; middle toe, .72 .

There are before me nine examples of this species, six of which have no more definite locality attached to them than "Brazil," while one of them has no indication whatever of locality. The other two are, respectively, from Rio Grande do Sul (No. 88453, U. S. Nat. Mus., H. von Jaering, collector), and Chapada, Matto Grosso (No. 33762, Am. Mus. Nat. Hist., H. H. Smith, collector).

Tinactor fuscus Max., which is quite universally cited as a synonym of Myiothera umbretta Licht., is so in part only. The two types, belonging to the American Museum of Natural History, are now before me, and are evidently the identical specimens from which the descriptions in the "Beiträge" were taken. The specimen described as the female is true $S$. umbretta, but that described as the male is identical with the Rio Napo bird, identified by Messrs. Sclater and Salvin with S. brunneus Scl., and if not really the latter must stand as a distinct form, S. fuscus Max. (See remarks under S. fuscus, on page 28.) 
S. umbretta is a strongly characterized species, easily distinguished from its nearest allies by the combination of bright chestnut rump and upper tail-coverts, with bright russet or tawny-rufous chest and olivebrown under parts, and is apparently entirely confined to Brazil south of the Amazon.

\section{Sclerurus albogularis SwaINs.}

Sclerurus albogularis SwaINs., B. Bras., 1834-'41, pl. 87; Zool. Jour., 1827.-JARD., Ann. and Mag. N. H., xix, 1847, 80 (Tobago).-Scl. \& SalV., P. Z. S., 1868, 627,630 (Venezuela).

Sp. CHAR.-Somewhat like S. umbretta, but lower throat plain light gray, upper throat and chin dull white, without distinct squamations, chest olive-tawny, and other under parts dull grayish olive.

НАв.-Venezuela and Tobago.

Adult (coll. P. L. Sclater, Venezuela, 1868; Goering).-Pileum and hind-neck, brownish olive; back similar, but slightly browner, becoming clear bistre posteriorly and changing to bright chestnut on rump and upper tail-coverts; tail dull brownish black, browner basally, especially on edges of the feathers. Chin and upper throat dull white, some of the feathers with very faint darker margins; lower throat plain dull light gray, the cheeks similar, but tinged with olive-brown; chest tawnyolive, approaching raw-umber; rest of under parts grayish olive, the under tail-coverts rusty brown (intermediate between vandyke-brown and burnt-umber). Upper mandible black, the tip and edges brownish; lower mandible with basal half whitish, terminal half brownish; legs and feet dusky brown. Length (skin), 6.50; wing, 3.40 ; tail, 2.50 ; exposed culmen, .80; tarsus, .85; middle toe, .77 .

A specimen in the U. S. National Museum collection from Tobago (No. 74884, April, F. A. (Ober) agrees exactly in coloration with the Venezuela specimen described above. It measures as follows: Length before skinning, 7.25; skin, 6.30 ; wing, 3.50 ; tail, 2.50 ; exposed culmen, .82 ; tarsus, .80 ; middle toe, .70 .

\section{Sclerurus canigularis, RIDGW.}

Sclerurus canigularis RIdGw., Proc. U. S. Nat. Mus., xi, 1889, 542.

SP. CHAR.-Somewhat like S. umbretta (Licht.), but much smaller and darker in color, the chest dark chestnut and the throat, abruptly, deep dull ash gray, fading into grayish white anteriorly.

НАв.-Costa Rica.

Adult male (type, No. 115038, U. S. Nat. Mus., Turrialba, Costa Rica, August, 1886; J. J. Cooper).-Prevailing color of upper parts plain dark sooty brown, orerlaid on hind-neck, back, scapulars, wing-coverts, and tertials, with a wash of burnt-umber, this changing to dark chestnut on rump and upper tail-coverts; tail brownish black. Sides of head dull grayish brown, this changing gradually to dull grayish white on chin and upper throat and to dull ash gray on lower throat; ehest deep chestnut brown (abruptly defined against gray of throat), this changing 
gradually into dull dark sooty brown on rest of under parts; lower tail-coverts tinged with dark chestnut. Upper mandible black, lower chiefly light colored; legs and feet brownish black. Length (skin), 6.00 ; wing, 3.45 ; tail, 2.55 ; exposed culmen, .85; tarsus, .85.

Since the above was written I have received a specimen of S. albogularis Scl. from Dr. P. L. Sclater, who writes me that my S. canigularis, the type of which was submitted to him for examination, is the same species. I can not, however, see why he should hold this view, since, placing side by side the type of S. canigularis, Dr. Sclater's S. albigularis (from Venezuela), and any one of several specimens of S. um. bretta (Light.) (from Brazil), it is at a glance obvious that S. canigularis is much more different from $S$. albigularis than the latter is from $S$. umbretta, though the two latter are distinct enough.

S. canigularis is altogether a darker-colorea bird than S. albogularis, of which the U.S. National Museum possesses an example from Tobago (No. 74884, F. A. Ober, collector), agreeing very closely with Dr. Sclater's Venezuelan specimen.

The differential characters of the three species may be expressed as follows:

$a^{1}$. Feathers of throat tipped or broadly margined with olive-brownish.

Under parts light bistre-brown, tinged with olive, becoming russet-brown on chest. Hab. Brazil ....................................... umbretta.

$a^{2}$. Feathers of throat without brownish tips or margins.

$b^{1}$. Under parts dull grayish olive, becoming tawny-olive on chest; back and scapulars bistre-brown tinged with olive; lower half of throat dull light gray; upper half, including chin, dull white. Hab. Venezuela and Tobago.

S. albogularis.

$b^{2}$. Under parts dark slaty, tinged, on tips of some feathers, with bright mummybrown, the chest deep burnt-umber brown; lower half of throat deep grayish; upper half, including chin, paler, but scarcely approaching white; back and scapulars deep vandyke-brown. Hab. Costa Rica.........S. canigularis.

\section{Sclerurus mexicanus ScL.}

? Sclerurus ruficollis SwaIns., "Birds Braz.," II ["1834-1841"], Tb. 79.

Sclerurus mexicanus Scl., P. Z. S., August 8, 1856, 290 (Cordova, Vera Cruz, Mexico) ; 1859, 365 (Jalapa); 1864, 175 (city of Mexico) ; Cat. Am. B., 1861, 149 (Cordova, Mexico ; Coban, Guat.).-Scl. \& Salv., Ibis, 1860, 35 (Coban); P. Z. S., 1867, 574 (Capim R., Lower Amazon), 750 (Yurimaguas and Chyavetas, E. Peru); Nom. Neotr., 1873, 62 (Mexico to Amazonia).-Lawr., Ann. Lyc. N. Y., VII, 1862, 465 (Panama).-SAlvin, P. Z. S., 1867, 14 (Veragua).-SumICHr., Mem. Bost. Soc., I, 1869, 555 (Vera Cruz).-Taczan., Orn. du Pérou, II, 1884, 115 (Yurimaguas).

Sclerurus gautemalensis (sic) Lawr., Ann. Lyc. N. Y., vir, May, 1863, 4 (Isth. Panama).*

* This reference of Mr. Lawrence's $S$. guatemalensis is made on the strength of his having previously mentioned the specimen to which it refers (under name of S. mexicanus) as having a rufous throat, which at once distinguishes $S$. mexicanus from $S$. guatemalensis. What is probably the very same specimen is now before me and is labeled in Mr. Lawrence's handwriting " Sclerurus gautimalensis." Its locality is Lion Hill, near Aspinwall (No. 41585, U. S. Nat. Mus.). 
? Sclerurus rufigularis Pelz., Orn. Bras., II Arb., 1869, 161 (Maribatanas; ex "Tïnactor rufigularis Natterer Catal. mse.").*

Sp. Char.-Above plain deep brown, duller (bistre) on head, changing to bright chestnut on rump and upper tail-coverts; tail dusky; throat and chest tawny or tawny-chestnut, the chin sometimes paler; rest of under parts similar to back, etc., but rather paler. Length (skin), about 6.00.

HaB.-Southern Mexico to Eastern Peru and Lower Amazons; Bahia?

Adult male (No. 42144, Protrero, Vera Cruz, February 20, 1866; F. Sumichrast).-Above bistre-brown, duller anteriorly, brighter on lower back, and changing to chestnut on rump and upper tail-coverts; tail dusky or dull blackish brown terminally, more brown basally, the feathers edged, except near tips, with the color of the lower back; edges of greater wing-covert and secondaries more rusty brown than back. Throat light russet or rusty cinnamon (chin paler), deepening on chest and upper breast into chestnut-russet; rest of under parts plain brown (intermediate between mummy-brown and bistre), the under tail coverts more rusty. Upper mandible blackish brown, lower pale brownish or brownish white, becoming dusky terminally ; tarsi clear brownish, toes darker. Length (skin), 6.00 ; wing, 3.15 ; tail, 2.40 ; exposed culmen, .95 ; tarsus, .85 ; middle toe, .70 .

Adult female (No. 42120, Mirador, Vera Cruz; C. Sartorius).-Similar to the male described above, but colors brighter, the entire throat, chest, and breast bright chestnut-tawny, lower parts more tinged with the same, and chestnut of rump and upper tail-coverts brighter. Length (skin), 5.90; wing, 3.20; tail, 2.40 ; exposed culmen, .95; tarsus, .80 ; middle toe, .70 .

Immature male (coill. Am. Mus. Nat. Hist., † Panama, 1862; J. McLeannan).--Similar to adults, but colors rather duller, especially on the throat and chest, where the color is paler or more tawny, some of the feathers with very indistinct duil brownish tips or margins and paler shaft-streaks.

An adult (sex not determined) from Guatemala (No. 30771, Coban, Vera Paz, March, 1860 ; O. Salvin), is much deeper colored than either of the Mexican skins described above, the upper parts being a very deep vandyke brown, and the throat a bright chestnut. Length (skin), 5.90 ; wing, 3.20 ; tail, 2.35 ; exposed culmen, .88; tarsus, .80 ; middle toe, .72 .

An adult male from the Isthmus of Panama (No. 41585, Lion Hill, near Aspinwall, J. McLeannan) is almost identical with the preceding in coloration, but is somewhat smaller, measuring as follows: Length

* Brunneus, dorso inferiore rufescente, gula et collo superiore ochraceis, pectore ferrugineo lavato, cauda nigrescente. Longit. (specim. exsicc.) $6^{\prime \prime}$, alæ $3^{\prime \prime} 1^{\prime \prime \prime}$, caudæ $2^{\prime \prime} 3^{\prime \prime \prime}$, rostri a rictn $11^{\prime \prime \prime}$, tars. 9 $\frac{1}{2}{ }^{\prime \prime \prime}$. (Pelz., l.c.)

† Lawrence collection. 
(skin), 5.60; wing, 3.10 ; tail, 2.35; exposed culmen (bill broken); tarsus, .85; middle toe, .72.

A specimen said to be from Bahia, in the collection of the American Museum of Natural History (Lawrence collection), agrees exactly in all essential features with the Panama and Guatemala specimens men. tioned above. It measures as follows: Length (skin), 6.35; wing, 3.40; tail. 2.70 ; exposed culmen, .85; tarsus, .S8; middle toe, .75 .

I have been unable to refer to the "Birds of Brazil" in order to ascertain whether the Sclerurus ruficollis of Swainson is the same as this species; but a specimen in the Lafrasnaye collection (No. 2323 ter.), kindly lent to me by the authorities of the Boston Society of Natural History, labeled "Sclerurus ruficollis Swains., Brazil," is so much like examples of S.mexicanus that I can not distinguish it satisfactorily. The only differences that I am able to find consist in the shorter bill (the exposed culmen measuring only .82 against .90-1.60 in Central American specimens), and rather lighter color of the pileum and hind-neck; but these differences are so slight that I am not inclined to regard them as of any importance or as representing more than a moderate extent of individual variation.

\section{Sclerurus caudacutus (VIEILL.).}

Thamnophilus caudacutus Vierll., Nouv. Dict., III, 1816, 310 (Guiana); Enc. Méth., 1823,742 .

? Myiothera caudacuta LAFr., Mag. de Zool., 1833, pl. 10.-Gray, Gen. B., I, 1846, 210.

Sclerurus caudacutus Bonap., Consp., I, 1850, 210.-Scl. \& Salv., P. Z. S., 1867, 573 (Capim R., Lower Amazon); Nom. Neotr., 1873, 62 (part).-SAlvin, Ibis, 1885, 419 (Br. Guiana).

? Sclerurus caudacutus, var., Pelz., Orn. Bras., II Arb., 1869, 86* (Maribatanas).

SP. CHAR.-Plain vandyke-brown, rather lighter beneath, where becoming russet on chest and tawny or ochraceous on throat; rump and upper tail-coverts more ruddy brown or burnt-umber; tail dusky brown.

НАв.-Guiana and Lower Amazons.

Adult (specimen in Lawrence collection, Am. Mus. Nat. Hist., from Cayenne).-A bove uniform clear vandyke-brown, becoming chestnutbrown or burnt-umber on rump and upper tail-coverts; tail dusky brown, lighter basally ; sides of head and neck, chest, and lower throat russet-brown, the under surface of the body, including under tail-coverts, similar in color to back, but paler, more of a mummy-brown hue. (Upper throat and chin apparently tawny or ochraceous, but the feathers of these parts wanting.) Bill brownish black, the basal half of the lower mandible brownish whitish; legs and feet brown. Length (skin),

* "A female and a male (from Maribatanas, April, 1831) are very similar to Sclerurus caudacutus, though somewhat smaller (but not so small, however, as those of No. 999 [S. rufigularis]); the tail is sborter, lower back brown like upper back, only the upper tail-coverts somewhat reddish-brown ( $S$. caudacutus has the lower back and upper tail-coverts dark rust-colored), and the upper breast hardly a trace of ochre." (PELz., l. c.; translation.) 
6.70 ; wing, 3.75 ; tail, 2.90 ; tarsus, .87 ; middle toe, .75 . broken.)

(Bill with tip Sclerurus fuscus (MAX.).

Tinactor fuscus Max., Beitr., III, 1831, 1106 (part ; male, but not female).

? Sclerurus caudacutus SCL. \& SALV., P. Z. S., 1867, 750 (Yurimaguas and Chyavetas, E. Peru.)

Sp. Char.-Uniform vandyke or mummy brown, slightly paler and more tawny on sides of head and neck and under portions of the same, and slightly more rufescent on rump and upper tail-coverts; feathers of chin and upper throat indistinctly paler basally.

HAB.-Upper Amazons.

Adult male (No. 6807, American Mus. Nat. Hist.; type of Tinactor fuscus Max.!)-Uniform bright vandyke-brown, inclining to mummybrown on under parts, the rump and upper tail-coverts inclining to burnt-umber, and the forehead, sides of head and neek (especially on malar region) lighter and more tawny, this color extending indistinctly around hind-neck; chin and upper throat dull brownish white, but this nearly hidden by broad brown tips to the feathers; lower throat and chest mummy-brown, like under parts of the body, but slightly tinged or mixed with tawny. Tail dark dull brown, less dusky toward base, especially on edge of feathers. Upper mandible with basal half blackish, terminal half and entire edge brownish; lower mandible whitish, brownish terminally. Length (mounted specimen), 6.50; wing, 3.55 ; tail, 2.90 ; exposed culmen, .80 .

Young male (No.32797, Rio Napo; maison Verreaux).--Uniform vandyke-brown, becoming burnt-umber on lower rump and upper tail coverts, lighter vandyke-brown, or almost mummy-brown, on chest, the throat and sides of head still slightly paler, the feathers of chin and upper throat pale brownish or dull brownish white basally ; tail blackish brown terminally, more brown basally and on edge of feathers. Upper mandible brownish black, browner terminally and on edges; lower mandible dusky brown, paler at base; legs and feet dusky brown. Length (skin), 7.40 ; wing, 3.50 ; tail, 2.75 ; exposed culmen, .80; tarsus, .87; middle toe, .75 .

The type of Tinactor fuscus Max., described above, is certainly specifically identical with the immature Rio Napo skin labeied by Verreaux "Sclerurus brunneus ScL., juv. o ." In fact, the two are absolutely alike in coloration, though the difference in the texture of the plumage shows at once that one is an adult and the other a young bird.

While there is considerable resemblance to S. brunneus ScL., the size is considerably greater, and there is no admixture of white on the throat, the latter showing distinctly even in a young bird of $S$. brunneus, from the Rio Ingador, Colombia. (See remarks on the latter, p. 29.)

The specinen described by Maximilian as the female of $T$. fuscus (Beitr., III, p. 1109) is a typical specimen of S. umbretta, and was probably from a different locality. Unfortunately Prince Maximilian does 
not specify the localities where his specimens were obtained, merely remarking that he obtained $T$. fuscus (including, of course, both species under this name) first in the forests of the river Itabapuana, between the parallels of $21^{\circ}$ and 220 south latitude, apparently a tributary of the Paraguay, and afterwards in the forests of the river Belmonte, in Eastern Brazil (province of Minas Geraes). If he met with these birds at only these two localities and obtained only the two specimens which formed part of his collection, it seems very probable that the type of T. fuscus came from the former locality, thus considerably extending the range of the species.

\section{Sclerurus brumneus ScL.}

Sclerurus brunneus ScL., P. Z. S., 1857, 17 (Bogota); (?) 1858, 62 (Rio Napo) ; Cat. Am. B., 1862, 149 (part).-Salvin, Ibis, 1885, 419.

Sp. CHAR.-Uniform reddish-brown or chocolate, the chin and upper throat white with brown or dusky margins to the feathers.*

НАв.-Colombia.

Young (No. 17505, Mus. Comp. Zool., Rio Ingador, near Pacific coast, Colombia; A. Schott).-Prevailing color deep chocolate-brown, the under parts paler and duller (intermediate between light vandykebrown and bistre); tail brownish-black; feathers of chin and upper throat white, broadly margined with blackish-brown; chest tinged with burnt-umber, the feathers with indistinct shaft-streaks of pale tawny. Wing, 3.30; tail, 2.30; exposed culmen, .77; tarsus, .83; middle toe, .72 .

I have not seen an adult specimen of this species, which Mr. Salvin regards as valid ( $c f$. Ibis, 1885, p. 419), which opinion is certainly decidedly indicated by the single immature example now before me. According to Dr. Sclater (P. Z. S., 1857, p. 18), it differs from its nearest allies as follows: "From S. caudacutus of Brazil [i.e., S. umbretta (Licht.)] and S. mexicanus * * * of Mexico and Guatemala it differs in the want of the bright rufous coloring in the rump and foreneck. In this respect it would seem to resemble Hartlaub's S. guatemalensis * * * but that bird is said to be of the size of S.caudacutus, to which the present species is inferior in dimensions."

\section{Sclerurus lawrencei, sp. nov.}

SP. Char.-Similar to S. guatemalensis (Hartl.), but much larger (wing, nearly 4.00; tail, 3.00 or more); the coloration of lower parts in the adult exactly as in the young of that species.

НАВ._-"Bahia" (but locality probably erroneous).

Adult female (Coll. Am. Mus. Nat. Hist., "Bahia"; Lawrence collection).-Above, warm bistre-brown, changing to burnt-umber on rump

* The characters ascribed in the original description, freely translated, are as follows: "Above, brown tinged with cinnamon; beneath, slightly paler; throat mixed with white; wings and tail-feathers with inner webs blackish, external margins similar in color to the back; bill black, the base yellowish; feet black. Total length, 6.00 ; wing, 3.40 ; tail, $2.10 . "$ 
and upper tail-coverts; tail brownish-black, browner at base; sides of head and neck light cinnamon-brown, indistinctly clouded or broken by dark, duller brown; chin and throat white, the feathers indistinctly margined with dull brown; chest dull tawny-brown (much like color of malar region and sides of neck), gradually changing into light bistre, tinged with raw-umber on other under parts. Bill dusky, with lower mandible chiefly pale brownish; legs and feet dusky brown. Length (skin), 7.30 ; wing, 3.95 ; tail, 3.10 ; exposed culmen, .80; tarsus, .93; middle toe, .78 .

This species, of which I have seen only the specimen described above, differs from $S$. umbretta in the brown instead of bright-chestnut color of the rump and upper tail-coverts, absence of reddish-brown on chest, and more distinctly white throat. It is also larger, though some specimens referred to $S$. umbretta approach it very closely in size.

\section{Sclerurus guatemalensis (HARTL.)}

Tinactor guatemalensis Hartl., Rev. Zool, 1844, 370.

Sclerurus guatemalensis ScL. \& SALv., P. Z.S., 1864, 354 (Panama) ; Nom. Neotr., 1873, 62 (Guatemala).

Scleurus [sic] caudacutus (VIEILl.) Lawr., Ann. Lyc. N. Y., viI, 1861, 320 (Panama ; nec Thamnophilus caudacutus VIEILL.).

Sp. ChAR.-Similar to S. umbretta (Light.), but darker, with rump and upper tail-coverts deep vandyke or bistre brown instead of bright chestnut, feathers of throat much more distinctly margined with dusky, and chest much less russet, as well as (usually) streaked or flecked with light tawny.

HAB.-Guatemala to Isthmus of Panama.

Adult male (No.1165̃89, Jiménez, Costa Rica, April, 1886; Anastasio Alfaro).-A Above uniform very deep vandyke-brown, somewhat brighter on wings and upper tail-coverts; tail brownish black. Chin and throat white, the feathers broadly margined with dusky; rest of under parts bistre or sepia, brighter on chest, where feathers have a central space (including shaft-streak) of light tawny. Bill blackish, basal half of lower mandible whitish; feet blackish brown. Length (skin), 6.60; wing, 3.50 ; tail, 2.60 ; exposed culmen, .85; tarsus, .90 ; middle toe, .75 .

Adult female (No. 64822, Sibuhue, Talamanca, Costa Rica, May, 1873; J. C. Zeledon).-Similar in plumage to the male, as described above. Length (skin), 6.20 ; wing, 3.50 ; tail, 2.60 ; exposed culmen (bill broken); tarsus, .87 ; middle toe, .75 .

Young female (Coll. Am. Mus. Nat. Hist., Panama, 1862 ; J. MeLeannan).*-Similar to the adult, but under parts much more uniform, the white of throat duller and with much less distinct squamations, the chest uniform mummy-brown, with only a few fine shaft-streaks of paler.

In addition to the three specimens described above, there are now before me a young female in transition plumage from Panama (No. 53806, McLeannan) and an adult male and two young birds (one a male) from 
Costa Rica, belonging to the Costa Rica National Museum. These show a considerable amount of individual variation, the two young birds from Costa Rica being particularly unlike, one resembling the Panama specimen described, though considerably darker above and less tinged with tawny beneath, while the other (No. 2334, male, San Carlos, December 25,1888, A. Alfaro) is very much darker throughout, the under parts being mainly of a dark sepia-brown.

\section{Sclerurus olivascens Cabanis.}

Sclerurus olivascens CAB., Jour. für Orn., Jan., 1873, 67 (Monterico, W. Peru).-TACzan., P. Z. S., 1874, 526 (Monterico); Orn. du Pérou, II, 1884, 115.

Hab.-Western Peru.

SP. Char.*-" Nearly uniform olive-brown; the breast more olive; throat whitish, undulated with olive; tail black." (Taczan., Orn. du Pérou, II, 1884, 115; translation.)

"Female adult.-General plumage of a dusky fuliginous-olive, the olive clearer on the under parts, especially on the breast; middle of the throat whitish, undulated with olive. Wings of the same color as the back; tail blackish. Bill brown, the lower mandible paler, whitish underneath; feet brown; iris deep brown.

"Length of the wing, 95; tail, 70 ; bill, 24 ; tarsus, 23 millimeters."

"Observations.-A form similar to the preceding [S. umbretta], the bill shorter and straighter, the general color more uniform, the rump concolor with the back." (Taczanowski, l.c.; translation.)

Smithsonian Institution, June 29, 1889.

* The original description, by Cabanis (l.c.), translated, is as follows: "In general resembling the Brazilian Sc. umbretta, with somewhat longer wings $\left(94^{\mathrm{mm}}\right)$. It differs in coloring by the want of the brownish red rump, which is uniformly colored with the other upper parts. The rusty reddish tinge to the whole plumage is replaced by a brownish olive color. Throat mixed with whitish. Hab. Monterico. Female. The male is still unknown. The female is characterized in all the species by the whitish throat. In the Brazilian S. umbretta the male has a rusty red throat. Sc. ruficollis Sws., which Gray considers identical with S. mexicanus, is the male of S. umbretta. On the other hand, the very similarly colored mexicanus is to be considered as the male of a somewhat smaller variety."

It may be remarked regarding the alleged sexual differences in color that, so far as I am aware, no other author appears to hold views similar to those expressed by Professor Cabanis. The circumstance that $S$. mexicanus inhabits the combined areas of several other species is of itself sufficient to disprove them, while even more convincing is the fact that in the series of specimens of the two Middle American species ( $S$. mexicanus and S.guatemalensis), both sexes, according to the determinations of the collectors, are represented in each. 


\section{$2 \mathrm{BHL}$ Biodiversity Heritage Library}

Ridgway, Robert. 1890. "A review of the genus Sclerurus of Swainson." Proceedings of the United States National Museum 12(762), 21-31. https://doi.org/10.5479/si.00963801.762.21.

View This Item Online: https://www.biodiversitylibrary.org/item/53609

DOI: https://doi.org/10.5479/si.00963801.762.21

Permalink: https://www.biodiversitylibrary.org/partpdf/52708

\section{Holding Institution}

Smithsonian Libraries

\section{Sponsored by}

Smithsonian

\section{Copyright \& Reuse}

Copyright Status: Public domain. The BHL considers that this work is no longer under copyright protection.

This document was created from content at the Biodiversity Heritage Library, the world's largest open access digital library for biodiversity literature and archives. Visit BHL at https://www.biodiversitylibrary.org. 